\title{
First mesonychid from the Clarno Formation (Eocene) of Oregon, USA
}

\author{
Selina V. Robson, Nicholas A. Famoso, \\ Edward Byrd Davis, and Samantha S.B. Hopkins
}

\begin{abstract}
A recently identified left dentary of Harpagolestes cf. uintensis represents the first mesonychid material known from the Pacific Northwest. The specimen is from the Hancock Quarry (Clarno Unit, John Day Fossil Beds National Monument), which is in the uppermost subunit of the Clarno Formation (middle Eocene, $\sim 40 \mathrm{Ma}$ ). The sediments of the Hancock Quarry were deposited by a meandering river system during the middle Eocene when north-central Oregon had a subtropical climate. As with many other mammals from the Hancock Quarry, Harpagolestes participated in an Asian-North American faunal interchange; species of Harpagolestes are known from the Eocene of both continents. Harpagolestes was carnivorous, and members of the genus were likely bone-crushers. Characteristic bone-crushing wear is visible on the occlusal surfaces of the Hancock Quarry specimen's premolars and molars. With the aid of CT scans, it has been determined that the Hancock Quarry Harpagolestes contains the alveoli for c1, p1-2, and m3, and preserves the crowns of p3-4 and m1-2. The molariform teeth have a large, conical trigonid with a bulbous talonid. The protoconid of $p 3$ and p4 is tilted posteriorly. This specimen of Harpagolestes cf. uintensis represents a new large carnivore in the Hancock Quarry ecosystem, adds to the known diversity of the Oregon middle Eocene, and is the only known occurrence of a mesonychid in the Pacific Northwest.
\end{abstract}

Selina V. Robson. Department of Biological Sciences, University of Calgary, 2500 University Drive Northwest, Calgary, Alberta T2N 1N4, Canada. selina.robson1@ucalgary.ca

Nicholas A. Famoso. U.S. National Park Service, John Day Fossil Beds National Monument, 32651

Highway 19, Kimberly, Oregon 97848, USA. nicholas_famoso@nps.gov

Edward Byrd Davis. Department of Earth Sciences, University of Oregon, 1272 University of Oregon, Eugene, Oregon 97403-1272, USA and Museum of Natural and Cultural History, University of Oregon, 1680 E. 15th Ave., Eugene, Oregon 97403-1224, USA. edavis@uoregon.edu

Samantha S.B. Hopkins. Robert D. Clark Honors College, University of Oregon, 1293 University of Oregon, Eugene, OR 97403-1293, USA/Department of Earth Sciences, University of Oregon, 1272 University of Oregon, Eugene, Oregon 97403-1272, USA. shopkins@uoregon.edu

Robson, Selina V., Famoso, Nicholas A., Davis, Edward Byrd, and Hopkins, Samantha S.B. 2019. First mesonychid from the Clarno Formation (Eocene) of Oregon, USA. Palaeontologia Electronica 22.2.35A 1-19. https://doi.org/10.26879/856 palaeo-electronica.org/content/2019/2585-first-mesonychid-from-oregon 


\section{INTRODUCTION}

The Hancock Quarry is a middle Eocene locality in the Clarno Formation of Oregon, equivalent to either the latest Uintan North American Land Mammal Age (NALMA) (Bestland et al., 1999; Lucas et al., 2004) or the early Duchesnean NALMA (Hanson, 1996; Lander and Hanson, 2006) (see Robinson et al., 2004 for a discussion of the Uintan and Duchesnean NALMAS). The locality is bracketed between 42.7 and $39.2 \mathrm{Ma}$ (Bestland et al., 1999). The Hancock Quarry represents one of a few Eocene mammalian localities in the Pacific Northwest (Pratt, 1998; Hanson, 1996; Fremd, 2010) and has produced over 2000 vertebrate specimens (Fremd, 2010), most of which are large-bodied animals estimated to be larger than $10 \mathrm{~kg}$ (Pratt, 1998; Hanson, 1996; Fremd, 2010). Taxa reported from the locality include Eubrontotherium (Mihlbachler, 2007), Teletaceras (Hanson, 1989, 1996), and Zaisanamynodon (Lucas, 2006), as well as rarer specimens of Plesiocolopirus (Radinsky, 1963; Schoch, 1989) and Diplobunops (Hanson, 1996; Emery et al., 2016). Smaller-bodied mammals including the horses Epihippus and Haplohippus (Hanson, 1996) and unidentified rodents (Hanson, 1996; Samuels and Korth, 2017) are also known from the Hancock Quarry. Previously only two carnivorous mammals, the "creodont" Hemipsalodon and an indeterminate nimravid, were known from the Hancock Quarry (Hanson, 1996). A third carnivorous mammal is now recognized: the specimen UOMNH F-36924, from the Lon Hancock field collections, is Harpagolestes cf. uintensis, a massive bone-cracking mesonychid.

Mesonychia is an order of archaic carnivorous ungulates that roamed the Holarctic during the Paleogene. Mesonychians possess a simplified upper dentition and a specialized lower dentition; their teeth are adapted for carnivory but lack the carnassials that evolved in carnivores and "creodonts" (Szalay, 1969). For many years, mesonychids were thought to be the ancestors or sister group of cetaceans (see Van Valen, 1966; O'Leary, 1998; Luo and Gingerich, 1999; O'Leary and Geisler, 1999; Gatesy and O'Leary, 2001), but mesonychids are now considered to be sister to the artiodactyls (which include cetaceans) (Shoshani,
1986; Gatesy et al., 1996, 2013; Gingerich et al., 2001; Thewissen et al., 2001; Geisler and Uhen, 2003, 2005; Geisler and Theodor, 2009; but see Williamson and Carr, 2007; Spaulding et al., 2009; Tabuce et al., 2011). Within Mesonychia, the family Mesonychidae contains the larger members, including the middle-late Eocene Harpagolestes. Species of Harpagolestes are known from Asia $(H$. leei, H. orientalis, H.? koreanicus) and North America $(H$. immanis, $H$. leotensis, $H$. macrocephalus, $H$. uintensis). Like most North American mesonychids, North American Harpagolestes are predominantly found in the continental interior (see Archibald, 1998 for a summary of the distriubtion). The Hancock Quarry $H$. cf. uintensis specimen is the first and only mesonychid known from the Pacific Northwest.

\section{MATERIALS AND METHODS}

The Hancock Quarry specimen (UOMNH F36924) still has plaster and burlap from the initial bedding jacket adhering to the specimen. Plaster on the lingual and occlusal surfaces was removed with deionized water and dental tools to expose the morphology while the buccal side remains jacketed to preserve the integrity of the specimen.

Computed tomography (CT) scanning was employed to reveal the covered surface and internal morphology, such as mineralized teeth. The specimen (UOMNH F-36924) was scanned with a Philips Brilliance 64 scanner at Oregon Imaging Centers in Eugene, Oregon. The scan was performed at an energy of $140 \mathrm{kV}$ and an intensity of $997 \mu \mathrm{A}$. A filter detail was used to reduce noise, and some orthogonal reconstructions were done post-scan. An image stack of 797 slices with a slice thickness of $0.9 \mathrm{~mm}$ and resolution of $512 \times 512$ was produced. The stack was imported into Amira 5.3 for Mac OS X (Visage, Inc., Chelmsford, MA; http://www.visage.com) where elements were digitized and a three-dimensional (3D) reconstruction of the teeth was created with the LabelFields module. Scans of the specimen and the reconstructed teeth are available on MorphoSource under the project heading "Robson et al. Harpagolestes project" (DOls: https://doi.org/10.17602/M2/M49061; https://doi.org/10.17602/M2/M49067; https:// doi.org/10.17602/M2/M65700). 
TABLE 1. Dental measurements of Harpagolestes cf. uintensis (UOMNH F-36924) compared to other Harpagolestes specimens. Measurements of the other Harpagolestes specimens are taken from the literature. In some cases, these measurements were reported in millimeters rather than tenths of millimeters. All alveolar measurements are at the bottom of the table.

\begin{tabular}{|c|c|c|c|c|c|c|c|c|c|}
\hline Species & & c1 & p1 & p2 & p3 & p4 & m1 & m2 & m3 \\
\hline H. cf. uintensis (UOMNH F- & L & & & & 27.8 & 25.1 & 31.5 & 24.0 & \\
\hline 36924) & W & & & & 12.5 & 14.2 & 14.1 & 16.5 & \\
\hline H. uintensis (YPM-PU 11659)* & L & & & 14 & & 28 & 31 & 29 & 18 \\
\hline (Scott and Osborn, 1889) & W & & & & & & 15 & 15 & \\
\hline H. uintensis (YPM 10072) & L & & & 20.7 & 28.0 & 27.5 & 31.5 & 23.0 & 19.0 \\
\hline (Thorpe, 1923) & W & & & & & & & & \\
\hline H. uintensis (CM 2961) & L & & & 21.0 & 26.0 & 30.0 & 29.0 & & \\
\hline (Gustafson, 1986) & W & & & 13.0 & 15.0 & 16.5 & 15.5 & & \\
\hline H. uintensis (AMNH 1878) & L & & & 16.7 & 28.3 & 30.0 & 24.3 & & \\
\hline (Gustafson, 1986) & W & & & & & & & & \\
\hline H. cf. uintensis (TMM 40498-3 & $\mathrm{L}$ & & & & & 31.5 & & & \\
\hline left) (Gustafson, 1986) & W & & & & & $16^{b}$ & & & \\
\hline H. cf. uintensis (TMM 40498-3 & L & 31.8 & 11.3 & & 29.4 & $31^{b}$ & & & \\
\hline right) (Gustafson, 1986) & W & 22.0 & 8.4 & & 15.5 & 16.9 & & & \\
\hline H. brevipes (YPM 13098)* (Jin, & L & & & & 31.5 & 34.0 & 37.0 & & \\
\hline 2005) & & & & 13.8 & 15.7 & 14.8 & & & \\
\hline H. immanis (AMNH 13143)* & $\mathrm{L}$ & 28.2 & & 21.7 & 30.4 & 32.8 & 30.2 & 31.5 & 21.7 \\
\hline (Szalay and Gould, 1966) & W & 19.3 & & 10.8 & 15.1 & 16.3 & 15.8 & 15.3 & 11.0 \\
\hline H. leotensis (CM 11778)* & & & & 20 & & 30 & 30 & 26 & \\
\hline (Peterson, 1931) & & & & & & & & & \\
\hline
\end{tabular}

Measurements of the Hancock Quarry specimen were taken with Pittsburgh digital calipers to the nearest $0.1 \mathrm{~mm}$. Additional measurements were made from CT scans of the specimen. The CT-based measurements were taken from scaled images with ImageJ (https://imagej.nih.gov/ij/) (Table 1).

Institutional Abbreviations. AMNH, American Museum of Natural History, New York, New York, USA; CM, Carnegie Museum of Natural History, Pittsburg, Pennsylvania, USA; IVPP, Institute of Vertebrate Paleontology and Paleoanthropology, Beijing, China; TMM, Texas Memorial Museum, Austin, Texas, USA; UCMP, University of California Museum of Paleontology, Berkeley, California, USA; UOMNH, University of Oregon Museum of Natural and Cultural History, Eugene, Oregon, USA; YPM, Yale Peabody Museum of Natural History, New Haven, Connecticut, USA.

\section{GEOLOGIC CONTEXT}

The Hancock Quarry is from the top of the Clarno Formation (Figure 1) and is geographically located within the Clarno Unit of John Day Fossil Beds National Monument. The quarry consists of tan siltstones, mudstones, and cobble conglomerate units and is about $5 \mathrm{~m}$ below the unconformable contact with the John Day Formation (Bestland et al., 1999; Hanson, 1996). These sedimentary units are $10 \mathrm{~m}$ thick while the bone-bearing deposits of the main locality are only $5.3 \mathrm{~m}$ thick, representing a normal grading sequence (Hanson, 1996). The Hancock Quarry is bracketed between Stony Tuff dated at $42.7 \pm 0.3 \mathrm{Ma}$ (Bestland et al., 1999) and Member A Ignimbrite at the base of the Big Basin Member of the John Day Formation dated at $39.22 \pm 0.03 \mathrm{Ma}$ (Bestland et al., 1999). 
TABLE 1 (continued).

\begin{tabular}{|c|c|c|c|c|c|c|c|c|c|}
\hline H. leotensis (CM 2961) & L & & & 21 & 26 & 30 & 29 & 27 & 19 \\
\hline (Peterson, 1931) & & & & 12 & 13 & 16 & 13 & & \\
\hline H. macrocephalus (YPM & L & & & & & 27.0 & 30.4 & 30.1 & 24.3 \\
\hline 11901)* (West, 1981) & & & & & & & 14.3 & 15.4 & 14.0 \\
\hline H. orientalis (IVPP V 13646) & L & 20.5 & 10.7 & 17.7 & 21.6 & 23.2 & 26.9 & & \\
\hline (Jin, 2005) & & 13.8 & 5.8 & 9.2 & 9.8 & 11.0 & 12.2 & & \\
\hline H. orientalis (IVPP V 13647) & L & & & 17.9 & & & & & \\
\hline (Jin, 2005) & & & & 9.9 & & & & & \\
\hline H.? koreanicus (repository & & & & & 20.5 & 20.8 & & & \\
\hline unknown) (Shikama, 1943) & & & & & 9.0 & 9.8 & & & \\
\hline \multicolumn{10}{|l|}{ Alveolar Measurements } \\
\hline H. cf. uintensis (UOMNH F- & $\mathrm{L}$ & 15.6 & $10.4^{a}$ & $29.0^{\mathrm{a}}$ & & & & & $16.5^{a}$ \\
\hline 36924) & W & 9.7 & $7.3^{a}$ & $10.5^{\mathrm{a}}$ & & & & & $7.5^{\mathrm{a}}$ \\
\hline H. cf. uintensis (TMM 40498-3 & $\mathrm{L}$ & & & 23.7 & & & 28.7 & & \\
\hline right) (Gustafson, 1986) & W & & & & & & & & \\
\hline
\end{tabular}

All measurements are in millimeters.

a Measurement is taken from the CT scan

b Measurement estimated (see Gustafson, 1986)

* Type specimen

Measurement abbreviations: L, anteroposterior length of tooth; $\mathbf{W}$, transverse width of tooth

\section{SYSTEMATIC PALEONTOLOGY}

Order MESONYCHIA Matthew, 1937

Family MESONYCHIDAE Cope, 1875

Genus HARPAGOLESTES Wortman, 1901

Type species. Harpagolestes macrocephalus Wortman, 1901, by original designation

Harpagolestes cf. uintensis (Scott, 1888)

Figures 2-4, Appendix 1
Referred specimen. UOMNH F-36924, left dentary with partial crowns of p2-m2 and alveoli of $\mathrm{c} 1$, $\mathrm{p} 1$, and $\mathrm{m} 3$ (Figures 2-4, Appendix 1).

Occurrence. UO 2473 (JDNM-13, UCMP V75203), Hancock Quarry, Wheeler County, Oregon, Clarno Formation. Precise locality information available to qualified researchers upon request.

Age. Late middle Eocene, either latest Uintan NALMA (Bestland et al., 1999; Lucas et al., 2004) or early Duchesnean NALMA (Hanson, 1996;

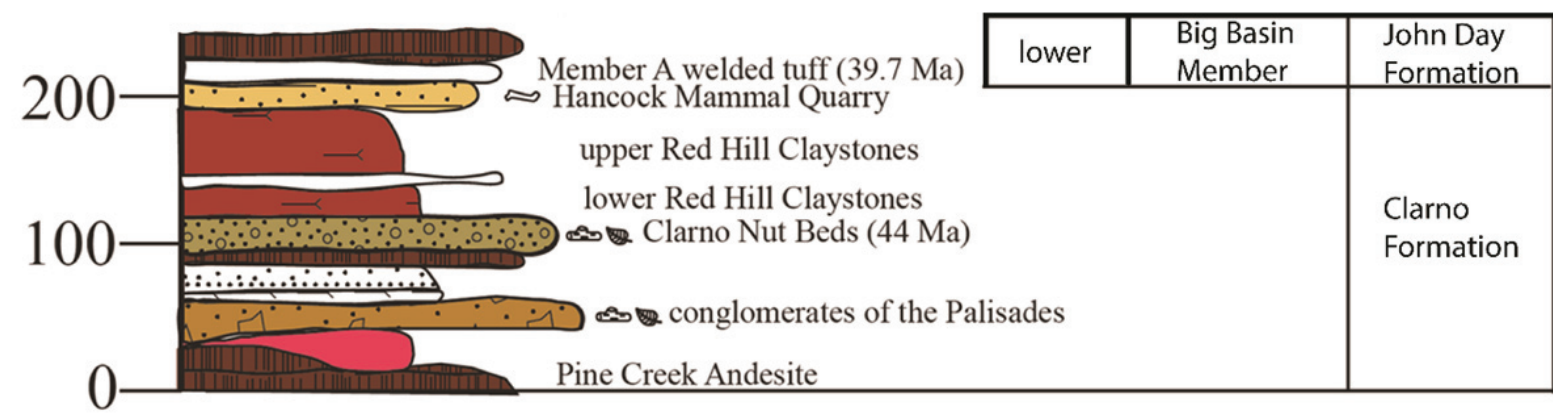

\section{meters grain size}

FIGURE 1. Stratigraphic column of the Clarno Formation with known fossil localities' stratigraphic positions indicated. Figure provided by the U.S. National Park Service. 


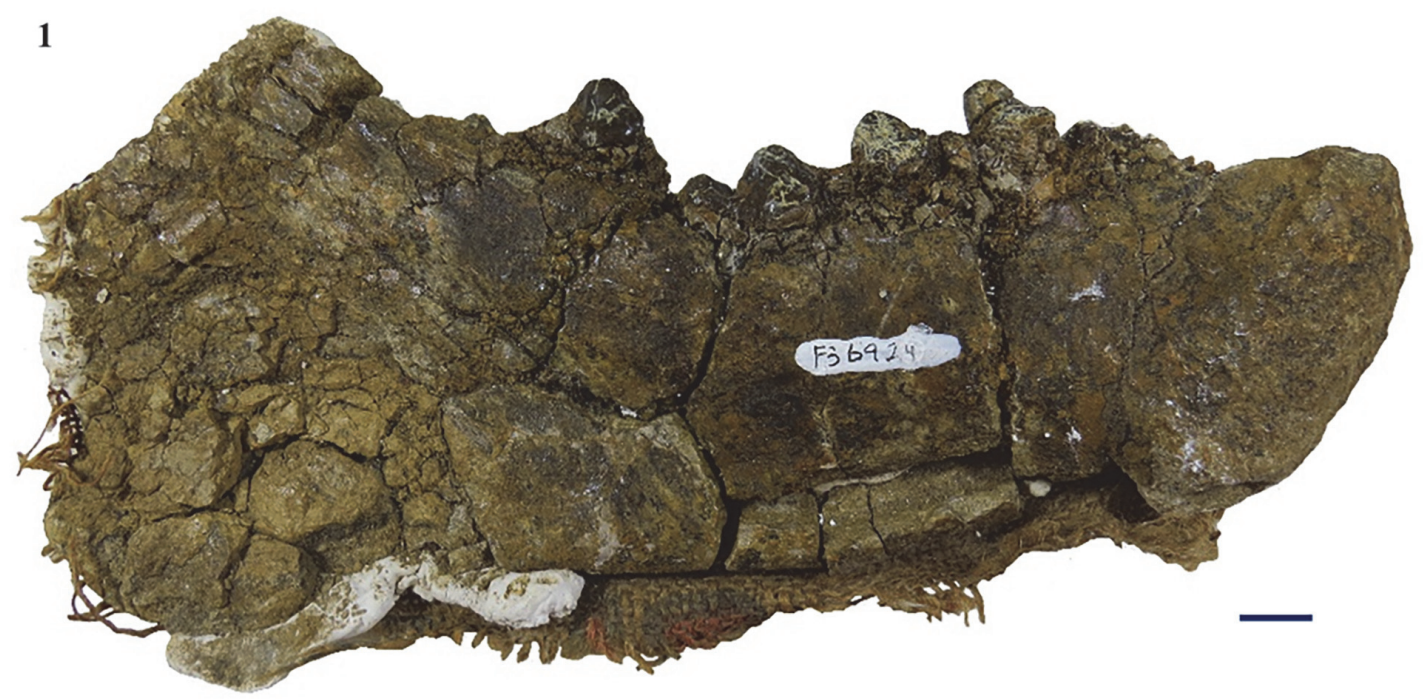

2

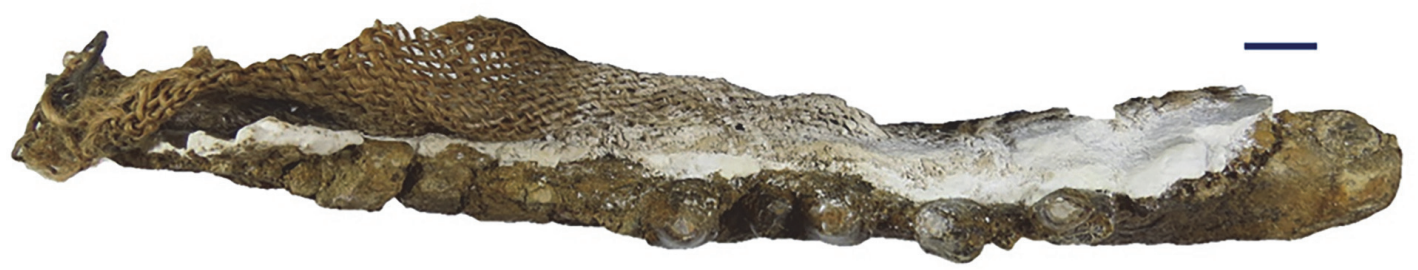

3

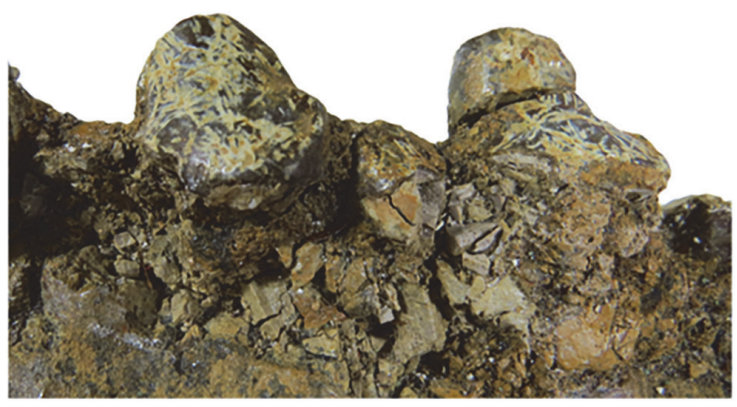

4

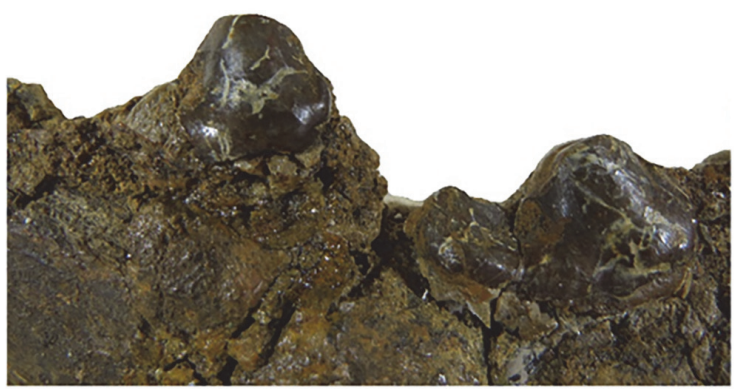

5

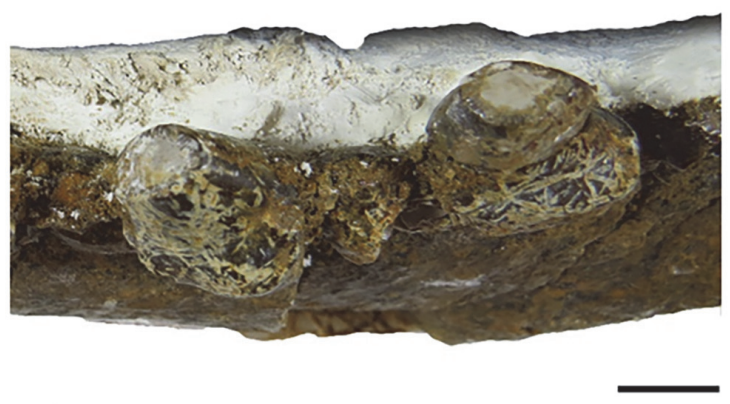

6

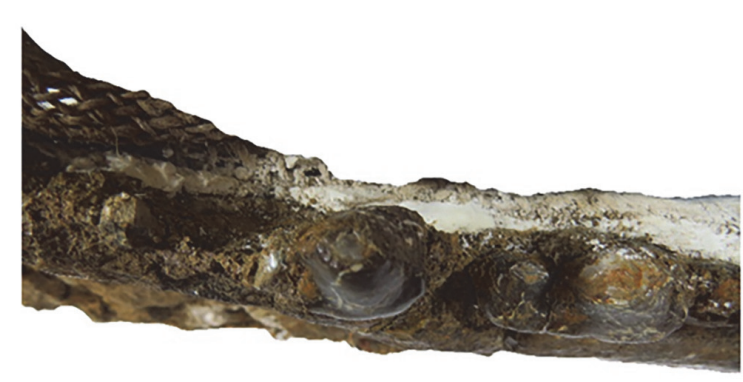

FIGURE 2. Harpagolestes cf. uintensis (UOMNH F-36924). 1, lingual view of full specimen; 2, occlusal view of full specimen; 3, lingual view of p3-p4; 4, lingual view of m1-m2; 5, occlusal view of p3-p4; 6, occlusal view of m1-m2. Anterior is facing toward the right. Scale bars equal $10 \mathrm{~mm}$. 


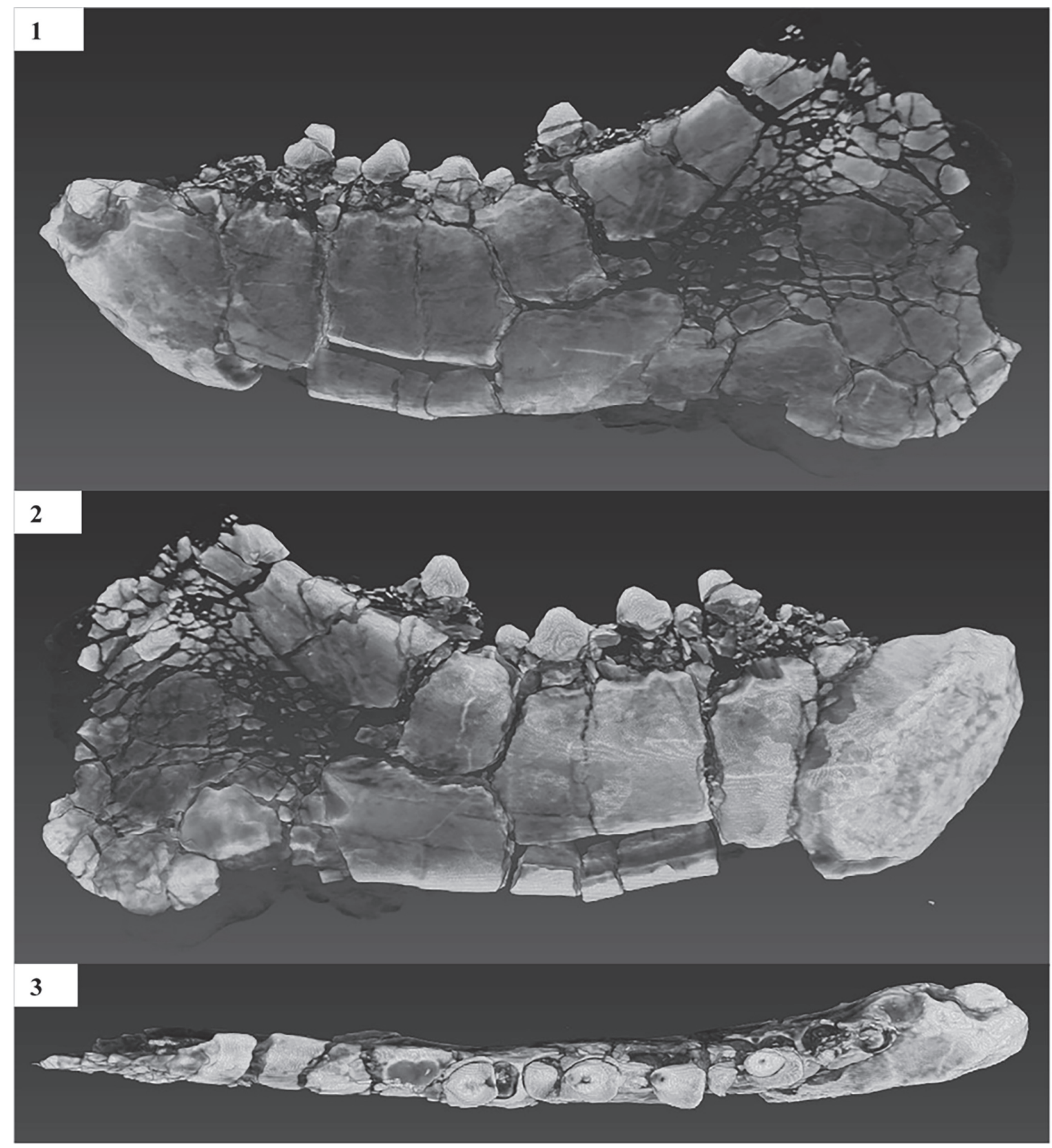

FIGURE 3. CT image of Harpagolestes cf. uintensis (UOMNH F-36924). 1, buccal view; 2, lingual view; 3, occlusal view. Anterior is facing towards the left in 1. Anterior is facing towards the right in 2-3. Scale bar equals $10 \mathrm{~mm}$.

Lander and Hanson, 2006). Bracketed between the Stony Tuff dated at $42.7 \pm 0.3 \mathrm{Ma}$ (Bestland et al., 1999) and the Member A Ignimbrite dated at $39.22 \pm 0.03 \mathrm{Ma}$ (Bestland et al., 1999).

Genus diagnosis. "Harpagolestes has a dental formula of 3.1.3(4).2/3.1.4.3 P3 is double-rooted; metacone is present on P4; parastyle on M1 is well developed while metastyle may be reduced; M2 is considerably wider than long, with a paracone subequal to the protocone and while metacone vestigial or absent; buccal cingulum is absent on P4$\mathrm{M} 2$; $\mathrm{p} 1$ is greatly reduced; metaconids are absent from m1-3; lacrimal-nasal contact is present in several species" (Zhou, 1995, p. 115).

Species diagnosis. "Large size; paraconid is reduced on lower molars; there are diastemata 


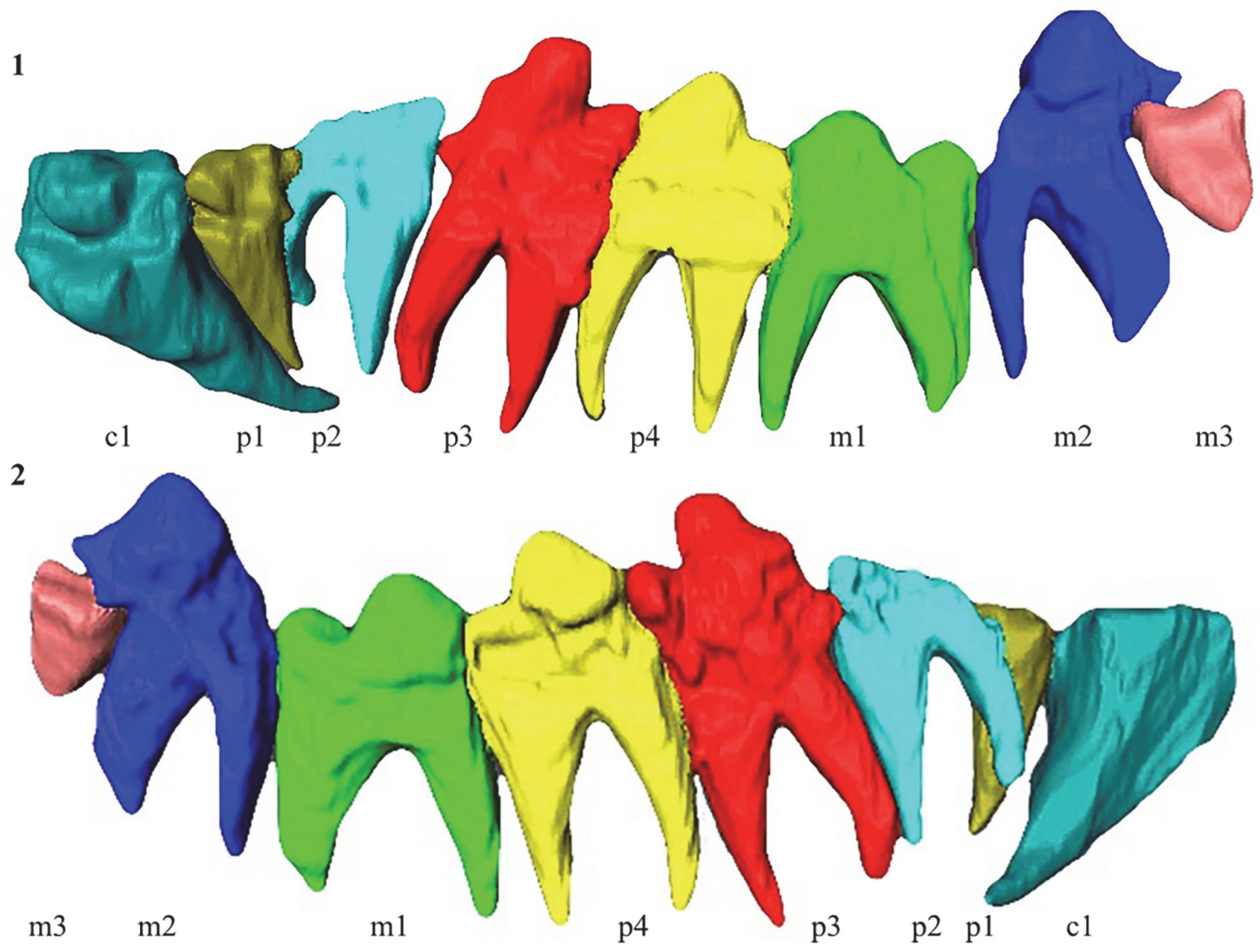

3

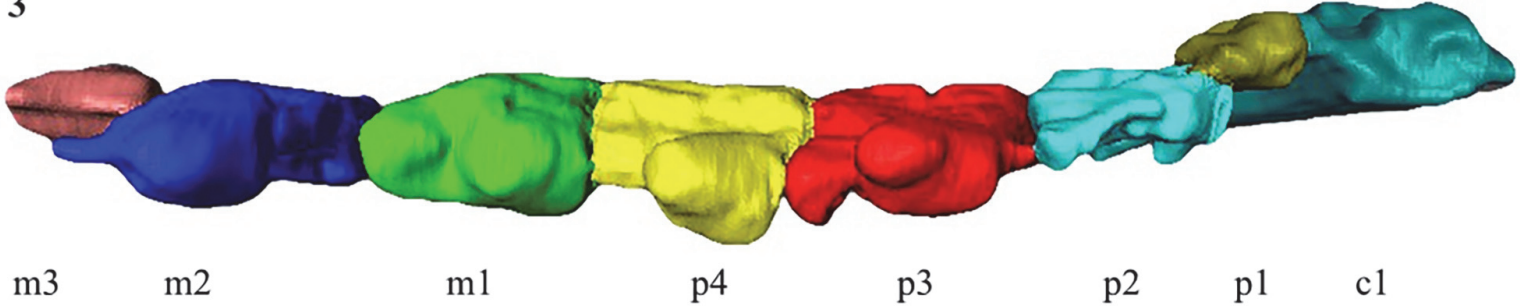

FIGURE 4. Three-dimensional reconstruction of Harpagolestes cf. uintensis (UOMNH F-36924) crowns and roots. 1, buccal view; 2, lingual view; 3 , occlusal view. Anterior is facing towards the left in $\mathbf{1}$. Anterior is facing towards the right in 2-3. Colors indicate tooth position. Scale bar equals $10 \mathrm{~mm}$.

between P1 and P2 and between P2 and P3" (Zhou, 1995, p. 118).

Description. UOMNH F-36924 is a left dentary that has been taphonomically deformed, mostly through anteroposterior compression. Much of the dentary is broken because of this deformation, and the portion anterior to $c 1$ is missing. The premolars have been shifted lingually from their natural position (Figure 3). The mandibular symphysis is intact, steep, and roughly oval in shape. The symphysis extends from the anterior breakage point to the posterior of p2. The horizontal ramus is deep, but the depth cannot be accurately determined because of deformation. Similarly, the ventral margin of the horizontal ramus appears to be slightly convex, but this convexity may be a result of deformation; the unbroken section of the ventral margin under $\mathrm{m} 2$ is straight. The angular process of the dentary is severely crushed, and the specimen is broken at the base of the ascending ramus. No foramina are visible on the specimen.

The incisors are absent because the dentary is broken anterior to $c 1$. The canine is broken at the base of the crown, with the root present. The shape of the root suggests that the canine was a 
large, anteroposteriorly compressed tooth (Figure 4, Appendix 1).

The $\mathrm{p} 1$ is not visible on the specimen. A CT scan has revealed that a small, single rooted $p 1$ was present, but the tooth is now missing and the alveolus is infilled with sediment (Figures 3-4, Appendix 1).

A relatively large, double-rooted $\mathrm{p} 2$ sits posterior to the $p 1$ alveolus. Most of the p2 crown has been shattered and lost; the few remaining fragments indicate that the tooth had a large trigonid and a relatively narrow talonid. The anterior root is bent lingually (Figure 4, Appendix 1.2). Whether this was a result of premolar crowding or postmortem deformation cannot be determined.

The $\mathrm{p} 3$ has a robust trigonid dominated by a conical protoconid. The tip of the protoconid is flattened from extensive occlusal wear. The trigonid is mostly intact and inclined posteriorly. However, the top of the trigonid was broken off and then reattached after collection. The angle of reattachment may not reflect the original orientation. Taphonomic deformation has resulted in the anteriormost portion of the trigonid being broken. Thus, the presence of a paraconid on p3 cannot be determined. The p3 talonid is present and appears to have had a single cusp, but damage precludes a more extensive description. Like the p2, the p3 is doublerooted.

The p4 is slightly larger than p3, but size is difficult to determine because of the postmortem anteroposterior compression and the anterior breakage of $\mathrm{p3}$. The CT scan shows that the anterior enamel of the p4 trigonid remains intact and that only the anterior root has been damaged (Appendix 1.2). Thus, the $\mathrm{p} 4$ lacks a paraconid and the large, posteriorly tilted trigonid is composed entirely of the conical protoconid. Like the p3, the p4 protoconid exhibits extensive wear on its occlusal surface. The p4 talonid, which is narrower than the trigonid, has extensive damage to its occlusal surface; little can be said about its morphology.

The double-rooted $\mathrm{m} 1$ is the most intact of the teeth. The $\mathrm{m} 1$ trigonid is dominated by a robust, conical protoconid that has an occlusal surface flattened by wear. Anterior breakage makes the presence of a paraconid impossible to determine, although a small protrusion on the anterolingual side suggests that a paraconid may have initially been present. The trigonid is wider than the talonid. There is a single cusp at the center of the talonid and a posterobuccal protrusion on the heel. A lingual cingulum extends from the anterior face of the protoconid to the posterior of the talonid.
Taphonomic distortion of the jaw has resulted in the $\mathrm{m} 2$ being elevated above the rest of the toothrow, and the trigonid has been forced into the space the talonid originally occupied. The trigonid is anteriorly damaged, but the occlusally worn conical protoconid is intact. There is a lingual cingulum and a slight anterolingual swelling that suggests a paraconid may have existed. The talonid has been broken, but the posterior root is still present. The remaining outline of the talonid is triangular with a narrow heel.

The $\mathrm{m} 3$ crown is missing, but the CT scan confirms that the tooth was originally present (Figure 3, Appendix 1.2). The scan shows a single alveolus which appears to be for a fused or partially fused double root. The size of the alveolus indicates that $\mathrm{m} 3$ was smaller than the other molars (Table 1).

\section{DISCUSSION}

\section{Comparison}

The Hancock Quarry specimen was compared to all species of Harpagolestes. Harpagolestes orientalis, $H$.? koreanicus, and $H$. leei are all smaller than the Hancock Quarry specimen (Table 1) (Jin, 2005, 2012). The only lower dentition of $H$. macrocephalus is a dentary with all teeth highly worn except for m3 (Wortman, 1901). Thus, no diagnostic morphological characters are available for $H$. macrocephalus lower dentition. However, the $\mathrm{m} 3$ of $H$. macrocephalus is relatively large $(24.3$ $\mathrm{mm}$ ) compared to the Hancock Quarry specimen $(16.5 \mathrm{~mm})$ (West, 1981). Harpagolestes brevipes is larger than the Hancock Quarry specimen and has a symphysis that extends more posteriorly (Thorpe, 1923; Zhou, 1995). Harpagolestes leotensis and $H$. immanis share many features with $H$. uintensis, and these taxa may be conspecific (Szalay and Gould, 1966; West, 1981; Gustafson, 1986). However, the species have not been formally synonymized. Both specimens of $H$. leotensis lower dentition (CM 117778; CM 2961) have a distinct paraconid on p4 while the Hancock Quarry specimen has a vestigial one (Peterson, 1931; Zhou, 1995). Szalay and Gould (1966, p. 144) note that, for $H$. immanis, "the teeth of the lower jaw are virtually identical with those of $H$. uintensis. The scarcity of specimens precludes further analysis." We attribute the Hancock Quarry specimen to $H$. cf. uintensis because the description of $H$. uintensis best matches the Hancock Quarry specimen. We have chosen to use the designation $H$. cf. uintensis rather than $H$. uintensis because some fea- 


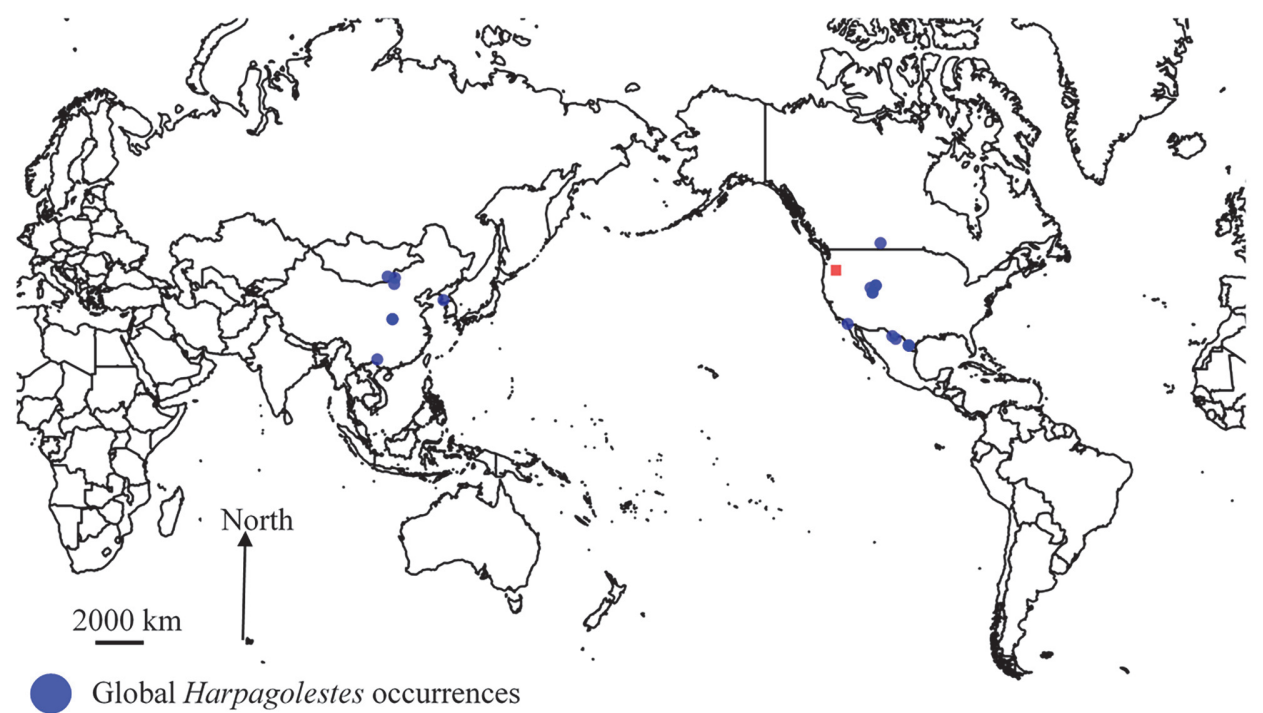

Hancock Quarry Harpagolestes cf. uintensis

FIGURE 5. Map of global Harpagolestes occurrences. Occurrence data were obtained from Shikama (1943), Kay (1957), Szalay and Gould (1966), Chow et al. (1973), Gazin (1976), Golz and Lillegraven (1977), Zheng and Chi (1978), Storer (1984), Gustafson (1986), Tomida and Lee (2004), Jin (2005, 2012).

tures of the specimen are ambiguous as a result of deformation.

\section{Paleogeography}

The Hancock Quarry specimen is a significant addition to the global distribution of mesonychids. North American mesonychids have been predominantly recovered from the Rocky Mountain and Great Plains regions (with one indeterminate mesonychid known from California), and no mesonychids were known from the limited Eocene fossil records of the Pacific Northwest (Archibald, 1998). Zhou (1995) suggested that many Eocene mesonychid genera originated in North America and migrated to Asia; however, there are coeval occurrences of Harpagolestes on both continents (e.g., Sazaly and Gould, 1966; Zhou, 1995; Jin, 2005), leaving the geographic origination of this genus indeterminable at present. Asian species of Harpagolestes are known from both the middle and late Eocene: $H$. leei and $H$. orientalis are from the middle Eocene of China and Mongolia, while H.? koreanicus is from the late Eocene of the Korean peninsula (Figure 5). Unfortunately, more precise stratigraphic ranges are not available for the Asian species.

Unlike the Asian Harpagolestes, all North American species are from the middle Eocene. The earliest occurrence is $H$. macrocephalus from the Wyoming Bridgerian NALMA (Gazin, 1976) (Figure 5). Most North American species are from the Uintan NALMA, including $H$. uintensis (Archibald, 1998). Harpagolestes uintensis has been found in Texas and Utah; coeval specimens of Harpagolestes are reported from Texas, Utah, Wyoming, California, and Saskatchewan (Figure 5). The latest known North American occurrence is an indeterminate Harpagolestes from the Duchesnean NALMA of Texas (Gustafson, 1986). The Hancock Quarry specimen is the first mesonychid described from the Pacific Northwest, adding to the known distribution of mesonychids. While the geographic origination still cannot be determined, the Hancock Quarry specimen does support the idea of mesonychid migration through the Bering region.

\section{ACKNOWLEDGMENTS}

We thank P. Holroyd (UCMP) for her preliminary identification of the specimen, advice about the HMQ nimravid, and for help with literature on the Clarno Formation. We also thank J. Theodor (U. Calgary) for her advice and for allowing us to use her lab resources. We are especially grateful to Oregon Imaging Centers for allowing us to use their CT scanner, and in particular N. Sumner who conducted the scan. We thank M. Summers (U. Calgary) and T. Fremd (U. Oregon) for helpful reviews of earlier versions of this manuscript. We 
also thank the handling editor, C. Haug (LMU Munich), the style editor, Y. Nakamura (Fujukan, Museum of the $U$. of the Ryukyus), and the anonymous reviewers for their helpful comments that greatly improved this manuscript. Lastly, we thank W. McLaughlin (Oberlin College) for her photos of the HMQ specimen.

\section{REFERENCES}

Archibald, J.D. 1998. Archaic ungulates ("Condylarthra”), p. 292-329. In Janis, C.M., Scott, K.M., and Jacobs, L.L. (eds.), Evolution of Tertiary Mammals of North America, Volume 1: Terrestrial Carnivores, Ungulates, and Ungulatelike Mammals. Cambridge University Press, Cambridge, United Kingdom.

Bestland, E.A., Hammond, P.E., Blackwell, D.L.S., Kays, M.A., Retallack, G.J., and Stimac, J. 1999. Geologic framework of the Clarno Unit, John Day Fossil Beds National Monument, Central Oregon. Oregon Geology, 61:1-39.

Chow, M.M., Chang, Y.-P., Wang, B.-Y., and Ting, S.-Y. 1973. New mammalian genera and species from the Paleocene of Nanhsiung, N. Kwangtung. Vertebrata PalAsiatica, 11:31-35. (In Chinese with English summary)

Cope, E.D. 1875. On the supposed Carnivora of the Eocene of the Rocky Mountains. Proceedings of the Academy of Natural Sciences, 27:444-449.

Emery, M.M., Davis, E.B., and Hopkins, S.S.B. 2016. Systematic reassessment of an agriochoerid oreodont from the Hancock Mammal Quarry, Clarno (Eocene, Duchesnean), Oregon. Journal of Vertebrate Paleontology, 36:e1041970. https://doi.org/10.1080/ 02724634.2015 .1041970

Fremd, T.J. 2010. Guidebook: SVP Field Symposium 2010, John Day Basin Field Conference, John Day Fossil Beds National Monument (and Surrounding Basin) Oregon, USA. Society of Vertebrate Paleontology, Bethesda.

Gatesy, J., Geisler, J.H., Chang, J., Buell, C., Berta, A., Meredith, R.W., Springer, M.S., and McGowen, M.R. 2013. A phylogenetic blueprint for a modern whale. Molecular Phylogenetics and Evolution, 66:479-506. https://doi.org/10.1016/j.ympev.2012.10.012

Gatesy, J., Hayashi, C., Cronin, M.A., and Arctander, P. 1996. Evidence from milk casein genes that cetaceans are close relatives of hippopotamid artiodactyls. Molecular Biology and Evolution, 13:954-963. https://doi.org/10.1093/oxfordjournals.molbev.a025663

Gatesy, J. and O'Leary, M.A. 2001. Deciphering whale origins with molecules and fossils. Trends in Ecology and Evolution, 16:562-570. https://doi.org/10.1016/s0169-5347(01)02359-x

Gazin, C.L. 1976. Mammalian faunal zones of the Bridger Middle Eocene. Smithsonian Contributions to Paleontology, 26:1-25. https://doi.org/10.5479/si.00810266.26.1

Geisler, J.H. and Theodor, J.M. 2009. Hippopotamus and whale phylogeny. Nature, 458:E1-E4. https://doi.org/10.1038/nature07776

Geisler, J.H. and Uhen, M.D. 2003. Morphological support for a close relationship between hippos and whales. Journal of Vertebrate Paleontology, 23:991-996. https://doi.org/10.1671/ 32

Geisler, J.H. and Uhen, M.D. 2005. Phylogenetic relationships of extinct cetartiodactyls: results of simultaneous analyses of molecular, morphological, and stratigraphic data. Journal of Mammalian Evolution, 12:145-160. https://doi.org/10.1007/s10914-005-4963-8

Gingerich, P.D., ul Haq, M., Zalmout, I.S., Khan, I.H., and Malkani, M.S. 2001. Origin of whales from early artiodactyls: hands and feet of Eocene Protocetidae from Pakistan. Science, 293:2239-2242. https://doi.org/10.1126/science.1063902

Golz, D.J. and Lillegraven, J.A. 1977. Summary of known occurrences of terrestrial vertebrates from Eocene strata of southern California. Contributions to Geology, University of Wyoming, 15:43-64.

Gustafson, E.P. 1986. Carnivorous mammals of the late Eocene and early Oligocene of TransPecos Texas. Bulletin of the Texas Memorial Museum of the University of Texas in Austin, 33:1-66. 
Hanson, C.B. 1989. Teletaceras radinskyi, a new primitive rhinocerotid from the late Eocene Clarno Formation of Oregon, p. 379-398. In Prothero, D.R. and Schoch, R.M. (eds.), The Evolution of Perissodactyls. Oxford University Press, New York.

Hanson, C.B. 1996. Stratigraphy and vertebrate faunas of the Bridgerian-Duchesnean Clarno Formation, North-Central Oregon, p. 206-239. In Prothero, D. and Emry, R.J. (eds.), The Terrestrial Eocene-Oligocene Transition in North America. Cambridge University Press, New York, New York. https://doi.org/10.1017/cbo9780511665431.012

Jin, X. 2005. Mesonychids from Lushi Basin, Henan Province, China. Vertebrata PalAsiatica, 43:151-164. (In Chinese with English summary)

Jin, X. 2012. New mesonychid (Mammalia) material from the lower Paleogene of the Erlain Basin, Nei Mongol, China. Vertebrata PalAsiatica, 50:245-257.

Kay, J.L. 1957. The Eocene vertebrates of the Uinta Basin, Utah, p. 110-115. In Seal, O.G. (ed.), Guidebook to the Geology of the Uinta Basin; Eighth Annual Field Conference. Intermountain Association of Petroleum Geologists, Salt Lake City, Utah.

Lander, E.B. and Hanson, C.B. 2006. Agriochoerus matthewi crassus (Artiodactyla, Agriochoeridae) of the late middle Eocene Hancock Quarry local fauna, Clarno Formation, John Day Basin, north-central Oregon. PaleoBios, 26:19-34.

Lucas, S.G. 2006. A new amynodontid (Mammalia, Perissodactyla) from the Eocene Clarno Formation, Oregon, and its biochronological significance. PaleoBios, 26:7-20.

Lucas, S.G., Zeigler, K.E., and Kondrashov, P.E. 2004. Archaenodon (Mammalia, Artiodactyla) from the Eocene Clarno Formation, Oregon, and the age of the Hancock Quarry local fauna. Paleogene Mammals, New Mexico Museum of Natural History and Science Bulletin, 26:8995.

Luo, Z. and Gingerich, P.D. 1999. Terrestrial Mesonychia to aquatic Cetacea: Transformation of the basicranium and evolution of hearing in whales. University of Michigan Papers on Paleontology, 31:1-98.

Matthew, W.D. 1937. Paleocene faunas of the San Juan Basin, New Mexico. Transactions of the American Philosophical Society, 30:1-510.

Mihlbachler, M.C. 2007. Eubrontotherium clarnoensis, a new genus and species of brontotheres (Brontotheriidae, Perissodactyla) from the Hancock Quarry, Clarno Formation, Wheeler County, Oregon. PaleoBios, 27:19-39.

O'Leary, M.A. 1998. Phylogenetic and morphometric reassessment of the dental evidence for a mesonychian and cetacean clade, p. 133-161. In Thewissen, J.G.M. (ed.), The Emergence of Whales. Plenum Press, New York. https://doi.org/10.1007/978-1-4899-0159-0_5

O'Leary, M.A. and Geisler, J.H. 1999. The position of Cetacea within Mammalia: phylogenetic analysis of morphological data from extinct and extant taxa. Systematic Biology, 48:455-490. https://doi.org/10.1080/106351599260102

Peterson, O.A. 1931. New mesonychids from the Uinta. Annals of Carnegie Museum, 20:333340.

Pratt, J. 1988. Paleoenvironment of the Eocene/Oligocene Hancock Mammal Quarry of the Upper Clarno Formation, Oregon. Ph.D. Dissertation, University of Oregon, Eugene, Oregon.

Radinsky, L. 1963. Origin and early evolution of North American Tapiroidea. Peabody Museum of Natural History Yale University, 17:1-100.

Robinson, P., Gunnell, G.F., Walsh, S.L., Clyde, W.C., Storer, J.E., Stucky, R.K., Froehlich, D.J., Ferrusquia-Villafranca, I., and McKenna, M.C. 2004. Wasatchian through Duchesnean biochronology, p. 106-155. In Woodburne, M.O. (ed.), Late Cretaceous and Cenozoic Mammals of North America: Biostratigraphy and Geochronology. Columbia University Press, New York. https://doi.org/10.7312/wood13040-006

Samuels, J.X. and Korth, W.W. 2017. The first Eocene rodents from the Pacific Northwest, USA. Palaeontologia Electronica 20.2.24A: 1-17. https://doi.org/10.26879/717 https://palaeo-electronica.org/content/2017/1874-eocene-rodents-from-oregon

Schoch, R.M. 1989. A review of tapirids, p. 298-320. In Prothero, D. R. and Schoch, R. M. (eds.), The Evolution of Perissodactyls. Oxford University Press, New York.

Scott, W.B. 1888. On some new and little known creodonts. Journal of Academy of Natural Sciences of Philadelphia, 9:155-185.

Shikama, T. 1943. A new Eocene creodont from the Hôsan coal mine, Tyôsen. Biogeographical Society of Japan. 13:8-11. 
Shoshani, J. 1986. Mammalian phylogeny: comparison of morphological and molecular results. Molecular Biology and Evolution, 3:230-240. https://doi.org/10.1093/ oxfordjournals.molbev.a040389

Spaulding, M., O'Leary, M., and Gatesy, J. 2009. Relationships of Cetacea (Artiodactyla) among mammals: increased taxon sampling alters interpretations of key fossils and character evolution. PLoS ONE, 4:1-14. https://doi.org/10.1371/journal.pone.0007062

Storer, J. E. 1984. Mammals of the Swift Current Creek Local Fauna (Eocene: Uintan), Saskatchewan. Natural History Contributions, Museum of Natural History, Regina, 7:1-158.

Szalay, F.S. 1969. Origin and evolution of function of the mesonychid condylarth feeding mechanism. Evolution, 23:703-720. https://doi.org/10.2307/2406864

Szalay, F.S. and Gould, S.J. 1966. Asiatic Mesonychidae (Mammalia, Condylarthra). Bulletin of The American Museum of Natural History, 132:127-174.

Tabuce, R., Clavel, J., and Antunes, M.T. 2011. A structural intermediate between triisodontids and mesonychians (Mammalia, Acreodi) from the earliest Eocene of Portugal. Naturwissenschaften, 98:145-155. https://doi.org/10.1007/s00114-010-0747-y

Thewissen, J.G., Williams, E.M., Roe, L.J., and Hussain, S.T. 2001. Skeletons of terrestrial cetaceans and the relationship of whales to artiodactyls. Nature, 413:277-281. https://doi.org/ $10.1038 / 35095005$

Thorpe, M.R. 1923. New species of Uinta Carnivora from White River, Utah. American Journal of Science, Series 5, 5:218-224. https://doi.org/10.2475/ajs.s5-5.27.218

Tomida, Y. and Lee, Y. 2004. A brief review of the Tertiary mammals from the Korean Peninsula. National Science Museum Monographs, 24:197-206.

Van Valen, L. 1966. Deltatheridia, a new order of mammals. Bulletin of the American Museum of Natural History, 132:1-126.

Wang, B. 1975. Paleocene mammals of Chaling Basin, Hunan. Vertebrata PalAsiatica, 13:154162. (In Chinese)

West, R.M. 1981. Geology and paleontology of the Bridger Formation, southern Green River Basin, southern Wyoming, Part 5. Harpagolestes macrocephalus and comments on structure, function and diversity of middle Eocene to early Oligocene large mesonychids. Contributions in Biology and Geology, Milwaukee Public Museum, 43:1-17.

Williamson, T.E. and Carr, T.D. 2007. Revision of the problematic early Paleocene genus Oxyclaenus (Mammalia: Oxyclaenidae) and a new species of Carcinodon. Journal of Vertebrate Paleontology 27:973-986. https://doi.org/10.1671/02724634(2007)27[973:rotpep]2.0.co;2

Wortman, J.L. 1901. Studies of Eocene Mammalia in the Marsh collection, Peabody Museum, Part 1. Carnivora. American Journal of Science, 12:1-90. https://doi.org/10.2475/ajs.s411.65.333

Zheng, J.-J. and Chi, H.-X. 1978. Some of the latest Eocene Condylarthra mammals from Guangsi, South Chia. Vertebrata PalAsiatica, 16:97-102. (In Chinese with English summary)

Zhou, X. 1995. Evolution of Paleocene-Eocene Mesonychidae (Mammalia, Mesonychia). Ph.D. Dissertation, University of Michigan, Ann Arbor, Michigan, USA. 


\section{APPENDIX 1.}

Interactive 3-dimensional reconstruction of Harpagolestes cf. uintensis (UOMNH F-36924). 1, Reconstruction of scanned surface; $\mathbf{2}$, Reconstruction of volumized toothrow. Available as a PDF only at https://palaeo-electronica.org/content/2019/2585-first-mesonychid-from-oregon. 